\title{
STOCHASTIC INVERSE MODELING OF GRAVITY DATA OF THE PROSPECTO JAGUAQUARA, BAHIA, BRAZIL
}

\author{
Eduardo M. S. Amarante (D) and Edson E. S. Sampaio (iD
}

\begin{abstract}
The ground gravity survey of the Jaguaquara Prospect followed the airborne magnetic survey aiming to correlate the gravity and magnetic anomalies. The determination of the density contrasts of the rocks is important to distinguish between mineralized and barren zones. Our goal was to determine the densities that allowed recovering the main observed gravimetric field features based on stochastic inversion. The regional gravity field was simulated by a two-dimensional linear function and subtracted from the Bouguer data to compute the residual gravity field. A singular value decomposition low-pass filter was applied to delete high frequency noise. This residual was submitted to a linear inverse modeling with the Particle Swarm Optimization algorithm with 300 bodies in two steps: optimizing the search window of the parameters using the estimator of the confidence interval in a population with 30 solutions; and computing the mean and the median of each parameter for another population of the same size and constructing two density models from these measurements of the central trend. The results showed that there is a zone with a possible enrichment of ferrous elements, probably due to hydrothermal alteration in a depth range of $50 \mathrm{~m}$ to $250 \mathrm{~m}$.
\end{abstract}

Keywords: Gravimetric anomalies, Prospect Jaguaquara, stochastic inverse modeling.

RESUMO. O acompanhamento gravimétrico da anomalia magnética de dados aerotransportados do Prospecto Jaguaquara teve como objetivo correlacionar as anomalias gravimétricas e magnéticas. A determinação dos contrastes de densidade das rochas é importante a fim de distinguir as zonas possivelmente mineralizadas das estéreis. O objetivo deste trabalho foi determinar as densidades que recuperassem as principais feições gravimétricas do campo observado a partir da inversão estocástica. O campo regional foi simulado através de uma função linear bidimensional que ao subtraí -lo do mapa Bouguer calculou-se o campo residual. Aplicamos o filtro passa-baixa de decomposição em valor singular para retirar os ruídos de alta frequência. Este resíduo foi submetido a uma modelagem linear inversa com o algoritmo Enxame de Partículas com 300 corpos em duas etapas. Inicialmente, construímos uma janela de busca otimizada para cada parâmetro usando o intervalo de confiança para uma população com 30 soluções. Por fim, calculamos a média e mediana de cada parâmetro para outra população do mesmo tamanho e foram construídos dois modelos de densidades a partir dessas medidas de tendência central. O resultado mostrou que na faixa de profundidade entre 50 a $250 \mathrm{~m}$ existe uma zona com possível enriquecimento de elementos ferrosos, provavelmente devido à alteração hidrotermal.

Palavras-chave: Anomalias gravimétricas, Prospecto Jaguaquara, modelagem inversa estocástica. 


\section{INTRODUCTION}

Studies carried out by Companhia Baiana de Pesquisa Mineral (CBPM) based on the airborne survey of the Rui Barbosa-Vitória da Conquista area, under contract with LASA/PROSPECTORS in 2006 revealed an expressive anomalous magnetic feature in the region of Jaguaquara, northeast of Brazil. The field evaluation of this anomaly showed the presence of intrusive alkaline rocks, hitherto not mapped in this region, besides hydrothermalites of calcium-sodium nature, forming albitites with epidote associated to magnetite enrichment under strong structural control (CBPM, 2014). Subsequently, the following studies were performed in the area: Aragão (2014) with gravimetry; Souza (2015) with magnetometry; Ribeiro (2018) with gamma ray spectrometry; and Anjos (2019) with geology. The present study employs the data from Aragão (2014) and extends its interpretation.

Gravimetry, specially when combined with other geophysical methods, may provide consistent results in the inverse modeling of the geophysical data (Kamm et al., 2015; Essa and Munschy, 2019), given that the anomalies suggest ore mineralization in the intrusive rock.

The Particle Swarm Optimization (PSO) is a stochastic inversion algorithm that searches a solution in the space of the initial models, so that the minimization does not depend on the initial model. It has been applied in several geophysical problems of different natures (Yuan et al., 2009; Wilken et al., 2009; Shaw and Srivastava, 2007; Singh and Biswas, 2016; Srivastava and Agarwal, 2010).

We present the statistical estimator confidence interval as a tool that allows developing windows of opti- mized search for each parameter in a linear and stochastic inverse modeling process of gravity data. This tool decreases the occurrence of outliers. From a set of solutions, we obtained two statistical models which explained the observed gravimetric data.

\section{FUNDAMENTS}

\section{Singular Value Decomposition (SVD)}

We can represent a given matrix $\mathbf{X}$ in the form of a sum of $r$ unit rank matrices, weighted by singular values $\sigma_{\mathbf{i}}$, whose products $\mathbf{u}_{\mathbf{i}} \mathbf{v}_{\mathbf{i}}^{T}$ represent matrix self-images (Lanczos, 1996),

$$
\mathbf{X}=\sum_{\mathbf{i}=1}^{\mathbf{r}} \sigma_{i} \mathbf{u}_{\mathbf{i}} \mathbf{v}_{\mathbf{i}}^{T} .
$$

Freire (1986) formulated three types of SVD filters as a function of self-images in the reconstruction of the matrix $\mathbf{X}$ whose functionality is similar to low pass, band pass and high pass filters. The application of these filters to potential field data aims to separate the regional component of the residual to isolate local anomalies, as well as to smooth the field by removing high frequency noise.

\section{Descriptive statistic}

A set of sample corresponds to a distribution of data or events within a domain set. Depending on the distribution, we can use the mean or the median descriptors as the more representative values. Understanding how the data was distributed gives a broad sense of how each data appears and its histogram representation shows the frequency as each data appears.

Confidence interval is a statistical estimator created around the point estimate that contains the true population parameter. Let $\theta$ be the parameter of interest of any random sample of a population, then the probability that $\theta$ be within a given confidence interval is:

$$
P\left(\hat{\theta_{0}}<\theta<\hat{\theta_{1}}\right)=100 \times(1-\alpha) \% .
$$

In Equation 2, $\left[\hat{\theta_{0}} ; \hat{\theta_{1}}\right]$ is the confidence interval, $100 \times$ $(1-\alpha) \%$ is the confidence level that provides the probability to contain the true parameter and $\alpha$ is a level of significance that represents the margin for stating that the defined interval contains the true parameter. The confidence level means that if we sample the population and calculate its average there is a probability that $100 \times(1-\alpha) \%$ of its average is within the confidence interval (Downey, 2011).

The implemented code that computes the limits of the confidence interval can be made available under request.

\section{PSO}

Particle Swarm Optimization (PSO) is a global scope optimization algorithm developed by Kennedy (2010) from the behavioral analysis of birds looking for food or a place to nest. Robust and with easy computational implementation, this algorithm solves the problems creating a population of particles, and moving those around the research space through cooperation and competition between them, according to simple mathematical formulas for the position and velocity of the particles.

Each particle $i$ has a current position, a current particle speed and its best position reached. The larger the size of the swarm (number of particles) the greater the computational cost.

PSO starts computing the random positions and velocities of each particle. Then, the objective function for every particle of the swarm is determined and it is verified which of them possesses the best verified position $\left(\rho_{\text {best }}\right)$ at a given step of the process. The best global position $\left(G_{b e s t}\right)$ of all the population is used to update the positions and the velocities of each particle.

The particle velocity is given by:

$$
\begin{aligned}
v_{i}(t+1)=v_{i}(t)= & c_{1} r_{1}(t) \times\left[\rho_{\text {best }}-x_{i}(t)\right]+ \\
& c_{2} r_{2}(t) \times\left[G_{\text {best }}-x_{i}(t)\right] .
\end{aligned}
$$

The products $c_{1} r_{1}(t)$ and $c_{2} r_{2}(t)$ of Equation 3 are called, respectively, cognitive and social components by Kennedy (2010). 


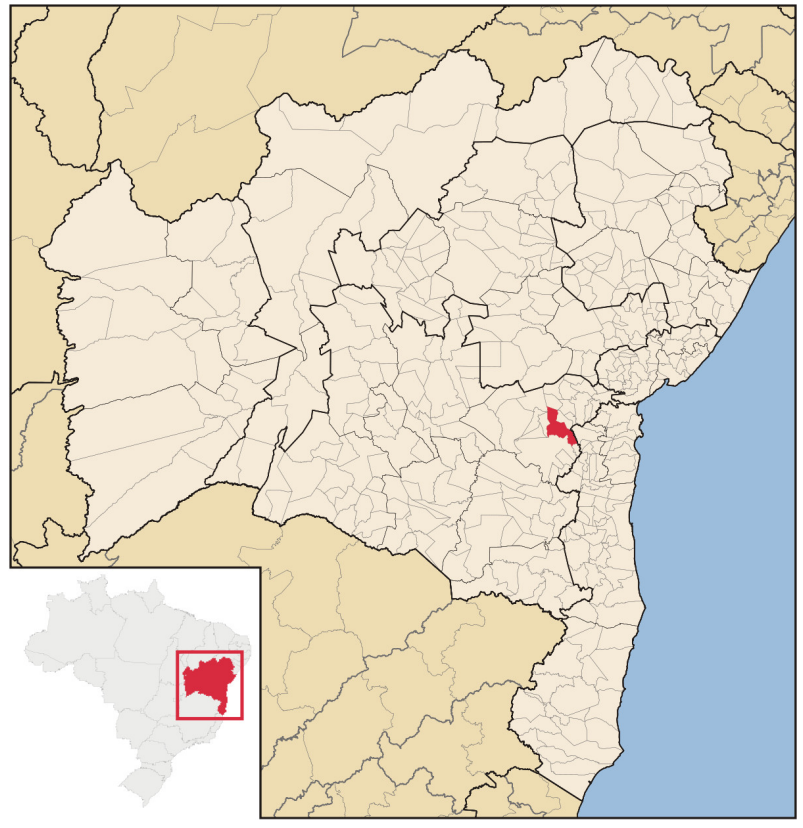

Figure 1. Location of the municipality of Jaguaquara in the State of Bahia.

\section{STUDY AREA}

Jaguaquara is in the State of Bahia, $328 \mathrm{~km}$ by road from the state capital, Salvador. Figure 1 shows the location of the municipality.

As to the geologic context, the study area is located at the interface between the Jequié (JB) and ItabunaSalvador-Curaçá (ISCB) blocks. JB is composed of granulitic orthogneisses of granitic and tonal composition, in addition to enderbytic and charnockitic rocks. The geology of the study area, as shown in Figure 2, is composed of a yellowish cover of detritic origin, ferruginous concretion, quartz shaft, tremolitite, albitized syenites and charnockite/enderbite gneiss (Barbosa et al., 2012).

The detritic cover is characterized by sandy-clayey, quartz, sub-angular and yellow-orange in color, sometimes with red tones. Ferruginous concretion occurs strictly and is characterized by a supergenic rock of fine granulometry, presenting brown ash color, composed essentially of fragments of quartz in the middle of a siliceous matrix with limonite and goethite.

Albitites are gray to pink colored rocks with greenish spots, fine grained to medium, deformed to a milonitized structure. In the few outcrops found, foliations occur concordant with the regional trend, in the NE-SW direction and dipping $85^{\circ} \mathrm{NW}$. Albitites occupy the central portion and, locally, the NW portion of the research area, at altitudes of $700 \mathrm{~m}$ and $750 \mathrm{~m}$.

The albitized syenite unit is composed of syenites, with local variation for monzonites, which exhibit varying degrees of albitization. These rocks have foliations trending, in general, NE-SW and dipping between $60^{\circ}$ and $80^{\circ}$ for both NW and SE (Anjos, 2019). They are rocks with color ranging from pink to white, have fine

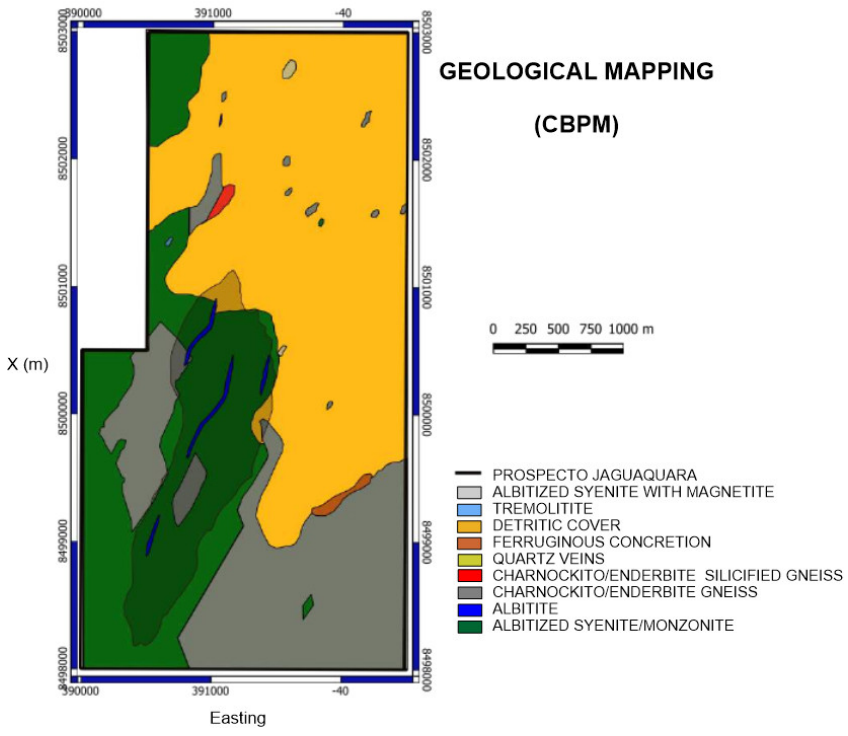

Figure 2. Geological map of Prospecto Jaguaquara (Silva et al., 2014; CBPM, 2014).

to medium particle sizes, locally coarse, gneissic to milonitic structure, millimeter to centimeter alternation of bands with magnetite-ilmenite and bands with quartz, sodium albite, clinopyroxene and amphibole.

The granulitic rocks (charnockite/enderbite-gneiss) have brown to dark gray color, fine to very coarse granulometry and foliated structure. They have a quartzfeldspar composition associated with hyperstene, biotite, amphibole and, sometimes, garnet. These rocks were intruded by alkaline rocks such as milonitized and metasomatized syenites as well as hydrothermalites from calcium-sodium purity, forming albitites with epidote associated to magnetite enrichment under strong structural control. The process of metasomatization is characterized by the presence of hydrothermal fluid compounds rich in Fe-Na-K-Ca, resulting in the formation of a matrix consisting of albite, debris microcline, aegirine, sodium amphibole and epidote (Silva et al., 2014; Anjos, 2019).

The hydrothermal process that took place in the area was responsible for the permeation of $\mathrm{Fe}$ and $\mathrm{Ti}$ that provided the formation of magnetite and ilmenite arranged in the deformation planes in the form of small euhedral to anhedral crystals (Silva et al., 2014).

\section{METHOD}

The gravimetric survey consisted of $21 \mathrm{~W}$-E profiles spaced $250 \mathrm{~m}$ with stations at every $20 \mathrm{~m}$ as shown in Figure 3 (Aragão, 2014). The Bouguer map, Figure 3 was obtained from the interpolation of the profile data with an $81 \times 81$ point mesh with the kriging interpolation technique.

To isolate the residual anomaly, it was necessary to estimate the regional with a first order polynomial, $f(x, y)=\alpha X+\beta Y+\gamma$. A least square procedure yielded: $\alpha=-1.770414 \times 10^{-4} ; \beta=-1.956505 \times 10^{-5}$; 


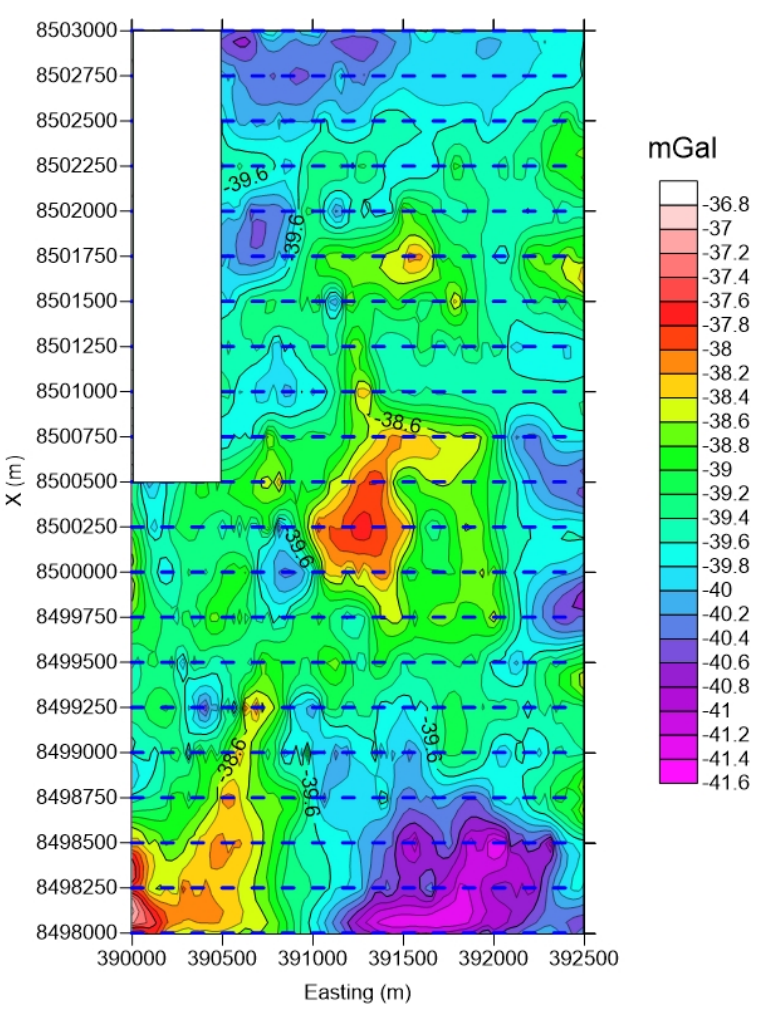

Figure 3. Bouguer Map showing the gravity profiles.

$\gamma=-39.157804$. The residual data, shown in Figure 4, was obtained by subtracting the regional data from the Bouguer data.

The residual field was filtered with the SVD low-pass filter with the cut set to the tenth singular value and the obtained field contains $79.91 \%$ of the information in the data matrix. The reconstruction of the data with the first 9 self-images eliminated the high frequency noise what can be seen in Figure 8c.

The area was discretized into 300 prisms distributed in three depth levels. Each prism has horizontal dimensions $a_{x}=500 \mathrm{~m}$ and $a_{y}=250 \mathrm{~m}$. The prisms of the first level of depth have a top at $Z=5 \mathrm{~m}$ and a bottom at $Z=50 \mathrm{~m}$, while the prisms of the two other levels are $200 \mathrm{~m}$ thick.

Figure 5 shows the distribution of parameters in the study area. The order of the distribution of the prisms was first in the $Z$ direction, then in the east-west direction and, finally, north-south. The gravimetric effect for the prisms was calculated with the subroutine gbox available in Blakely (1996).

The PSO program was configured to invert the data with a cluster of 200 particles and 70 iterations to search for density contrasts in the range of $-250 \mathrm{~kg} / \mathrm{m}^{3}$ to $+300 \mathrm{~kg} / \mathrm{m}^{3}$. A set of 30 solutions was created with the calculated density contrasts. Each sample of parameters was analyzed individually to check which value for the parameters was most representative and to build a new search window from the statistical confidence interval estimator. The results were grouped by parameters that were analyzed separately in order to build individual search windows using the confidence interval statistical

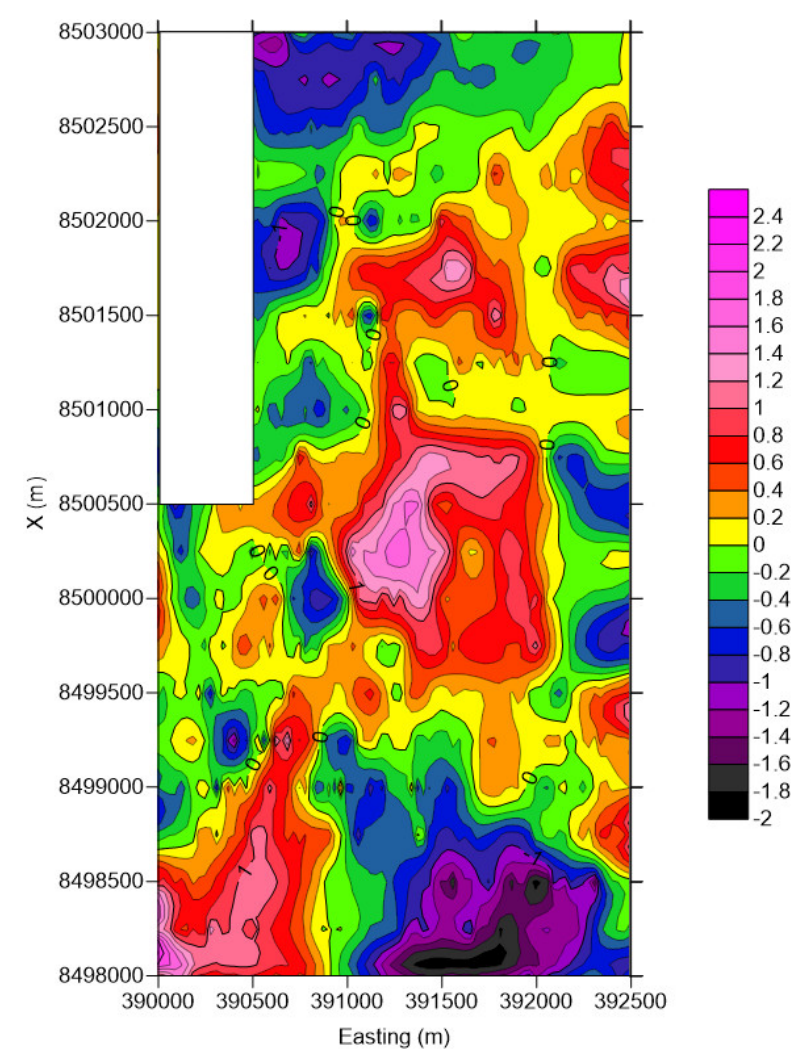

Figure 4. Residual map in mGal.

estimator. The lower and upper limits of the $99 \%$ confidence interval were set to be the upper and lower limits of the new window search. From this step on, each parameter had a specific and optimized search window. Figure 6 shows the distribution curve and the reduction of the search space for one of the parameter when taking into account the confidence interval.

\section{RESULTS}

A new population of solutions was obtained with 30 samples, and we realized that the median of the distribution had a density contrast value very close to the average. The model with the average values presented MSE error equal to $0.0969 \mathrm{mGal}^{2}$ and the model with the median values had MSE error equal to 0.0844 $\mathrm{mGa}^{2}$, therefore, the model with the median values was considered the final solution of this work.

Figure 7 shows the fit of the curves calculated to the data observed and Figure 8 compares the observed anomaly map with those calculated with the obtained models.

Figure 9 shows the density contrasts of the interpolated raw materials for each depth level. The interpolation was performed by the Surfer program using the interpolation technique known as Nearest Neighbors. We used this interpolation technique because its algorithm fills the empty spaces with information of the nearest points instead of a new value (Olivier and Hanqiang, 2012). Besides the concentration from the higher density values being in the range $50 \mathrm{~m}$ to $250 \mathrm{~m}$ deep, the 


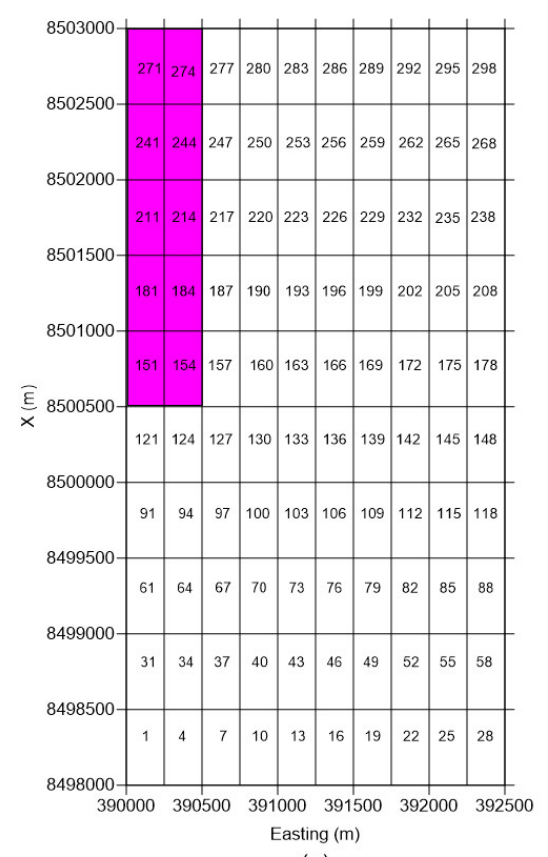

(a)

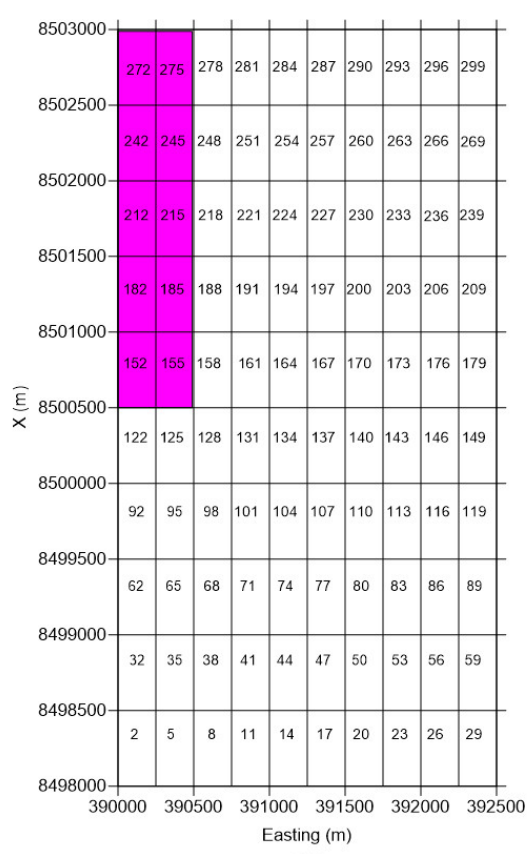

(b)

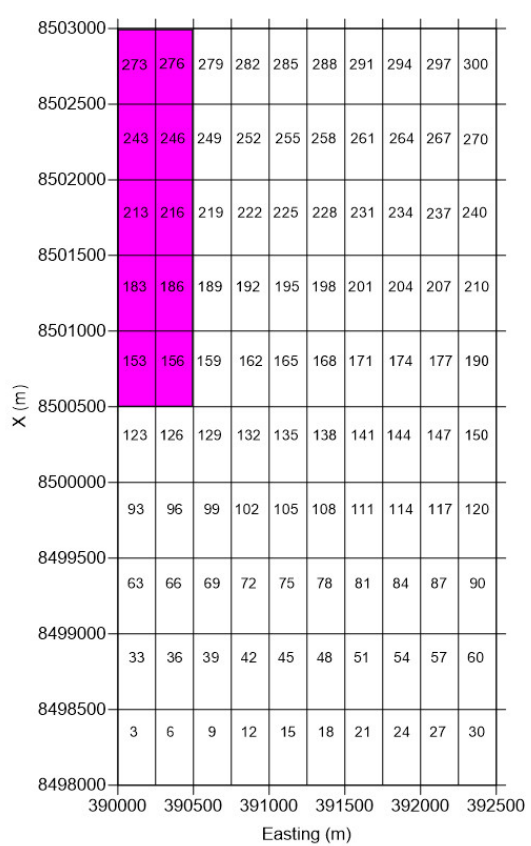

(c)

Figure 5. Distribution of parameters in the area. The bodies with pink color were not taken into account in the inversion procedure.

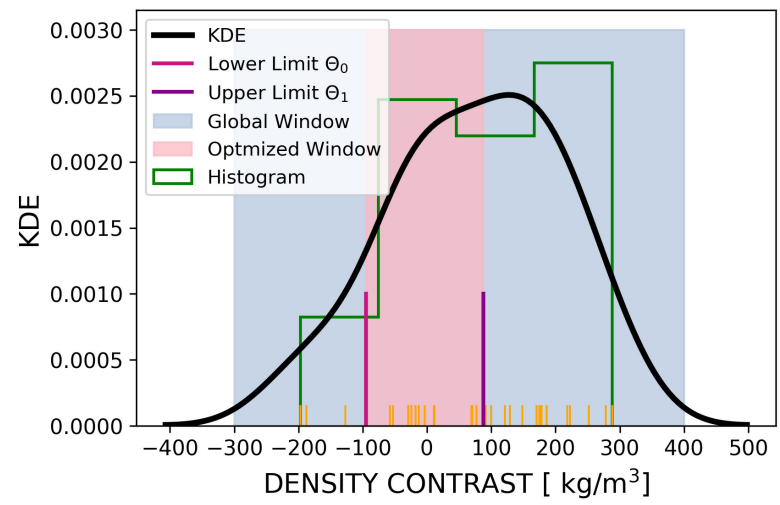

Figure 6. Probability distribution of density contrast. In blue, we have the global search window and in pink, the $99.99 \%$ confidence interval that corresponds to the optimized window of search for this parameter with limits $\theta_{0}$ and $\theta_{1}$. The values obtained with the stochastic inversions are in orange. KDE is the kernel density estimation.

density distribution in this depth range explains the observed anomalies in terms of the shape of the contours. This depth range contains the tops of the probable gravity sources (Ribeiro, 2018). Figure 8 also shows that the model reasonably defines the distribution of density values along the depth.

The largest density contrasts are associated with the process of hydrothermal alteration that led to albitization events, enrichment with iron, and formation of crystals of ilmenite and magnetite (Anjos, 2019). Although the region has been extensively studied (Aragão, 2014; Souza, 2015; Ribeiro, 2018; Anjos, 2019), there is still a lack of information about the subsurface geology that could help to understand the variation of the densities with depth.

\section{CONCLUSIONS}

SVD was indispensable in the filtering process, as it allowed the removal of high frequency noise. The PSO proved to be efficient in the gravimetric inverse modeling process when there is enough amount of data to perform a statistical analysis. The calculation of the confidence region was important because besides obtaining an optimized and individualized search window for each body in the process of inversion, it eliminated the presence of outliers.

The $99.99 \%$ confidence level was adequate, as a smaller confidence would imply that the search for density contrasts would fall within the density variation of the lithological unit. The mean and median values were very close, suggesting that both may represent the density of the same lithological unit.

The density model developed explains well the gravimetric phenomenon observed and can be associated to a hydrothermal alteration that can be enriched with $\mathrm{Fe}$ and $\mathrm{Ti}$ elements in the region where a contrast of $240 \mathrm{~kg} / \mathrm{m}^{3}$ was found.

However, the gravity study alone is not sufficient for defining a mineralized target. So, we decided just to indicate the 3 levels of density contrasts. This information will be useful because, integrated to other geophysical, geochemical and geological data, may define possible ore targets. 

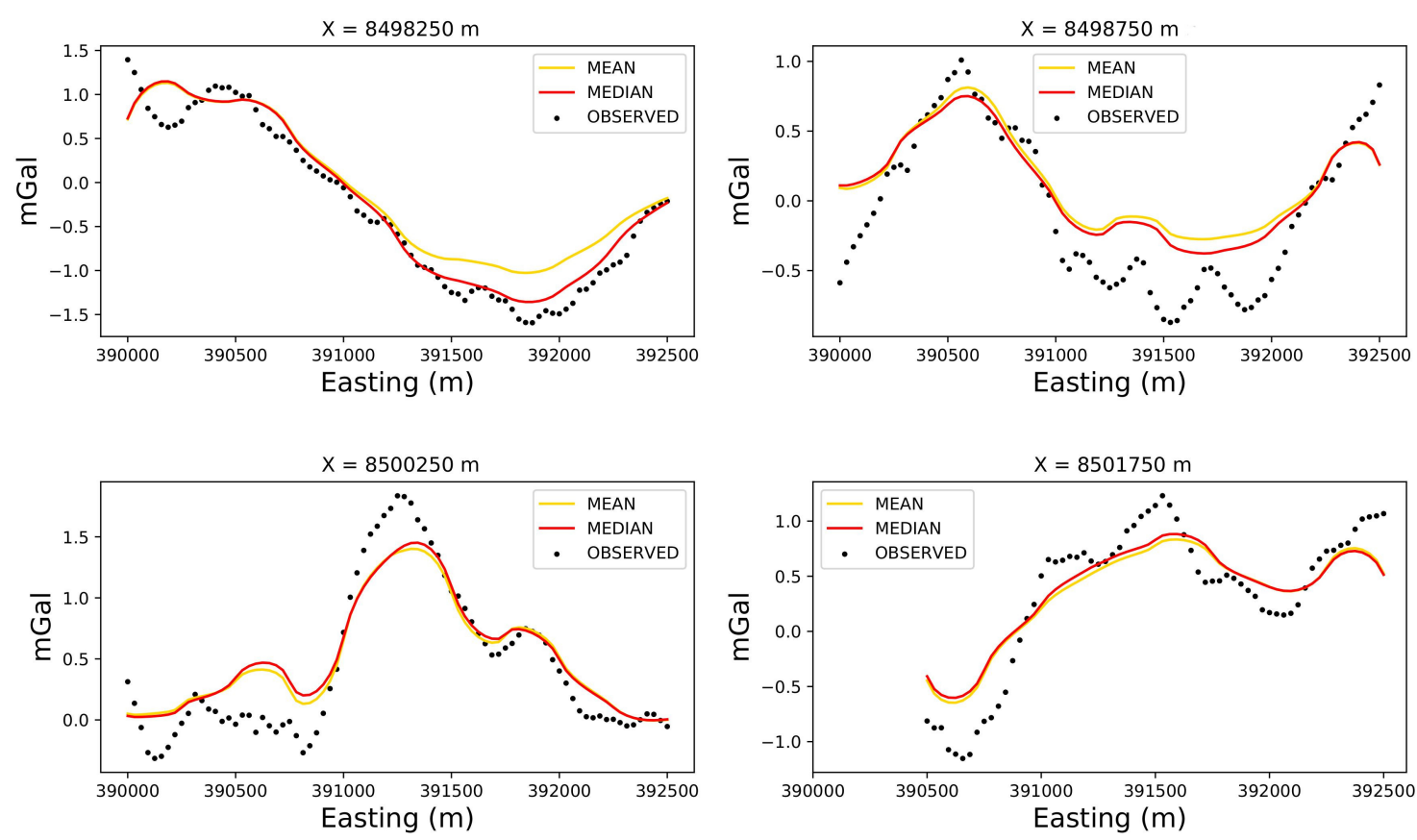

Figure 7. Field adjustment calculated with the median and the average of the data observed in the profiles indicated in Figure 8(c).

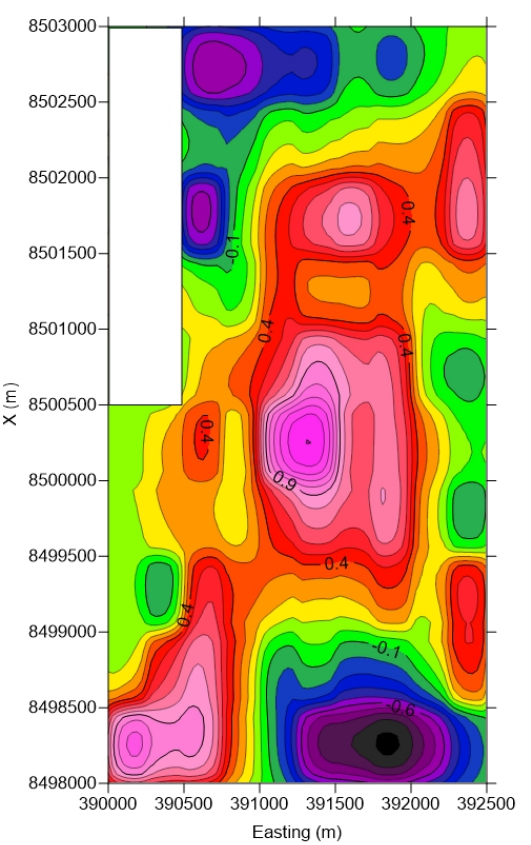

(a)

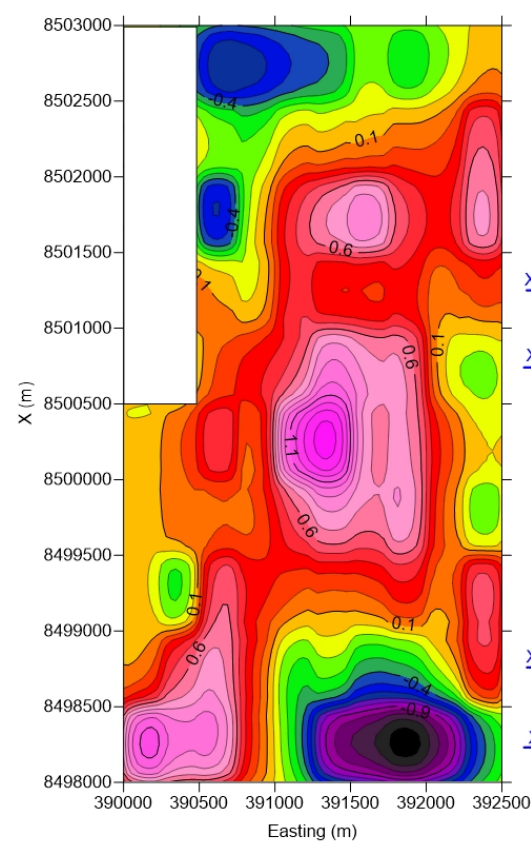

(b)

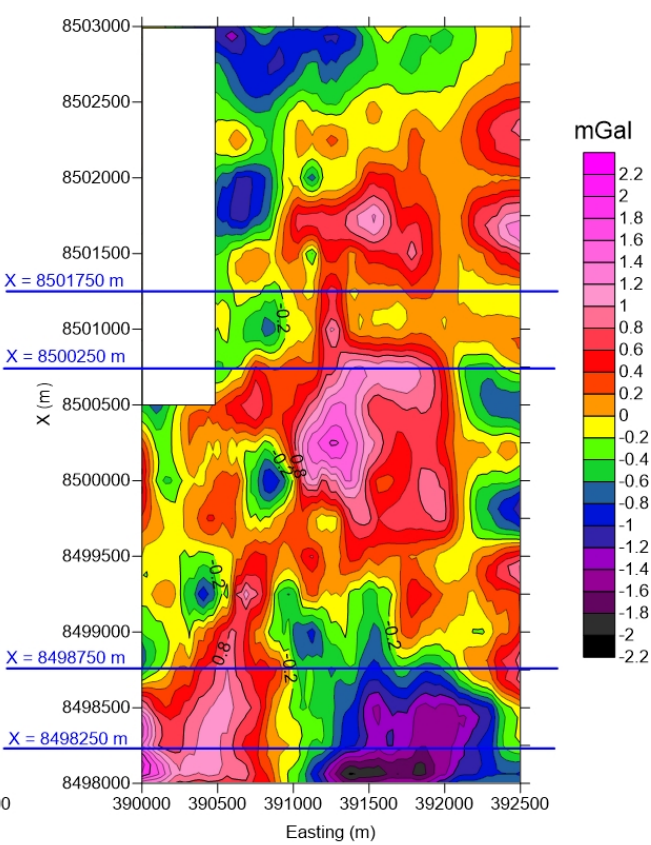

(c)

Figure 8. Maps of anomalies in mGal: (a) calculated with the median values for density; (b) calculated with the average of the solutions; (c) observed data. 


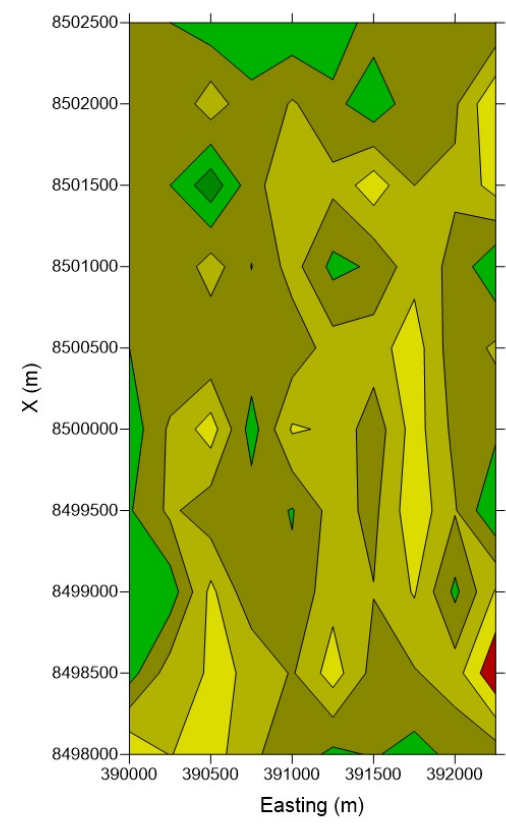

(a)

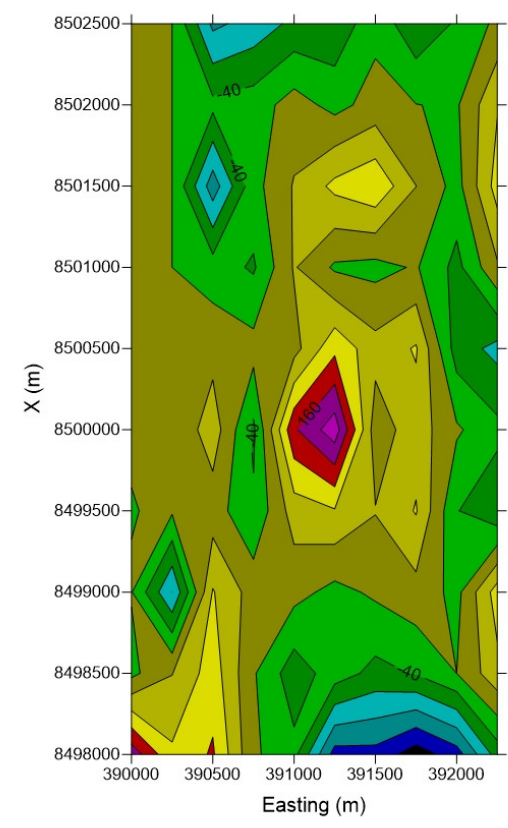

(b)

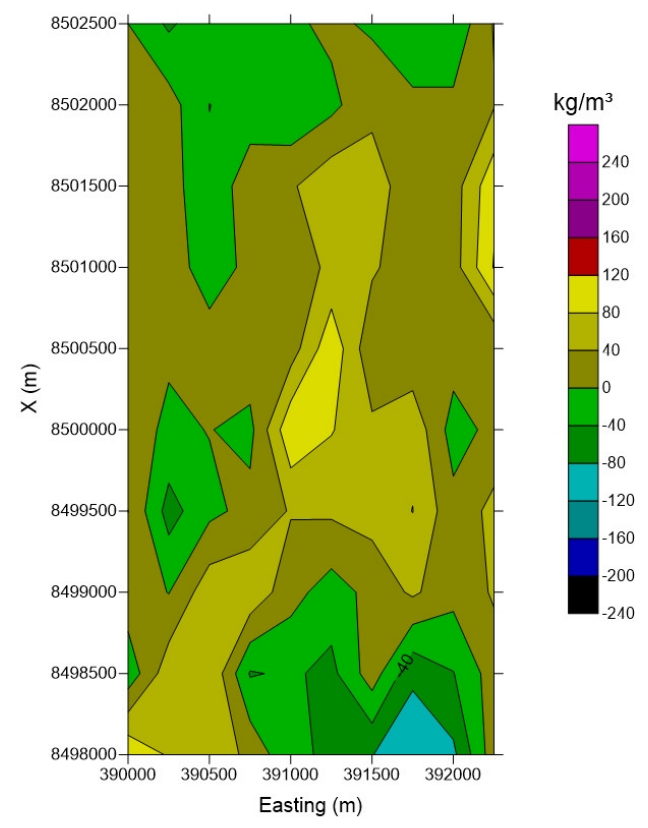

(c)

Figure 9. Density contrast model obtained with the inversion of gravimetric data in three depth levels. Top depths at: (a) $5 \mathrm{~m}$, (b) $50 \mathrm{~m}$ and (c) $250 \mathrm{~m}$.

\section{APPENDIX}

The Python code was used to determine the confidence interval with a level of $99,99 \%$ for each parameter.

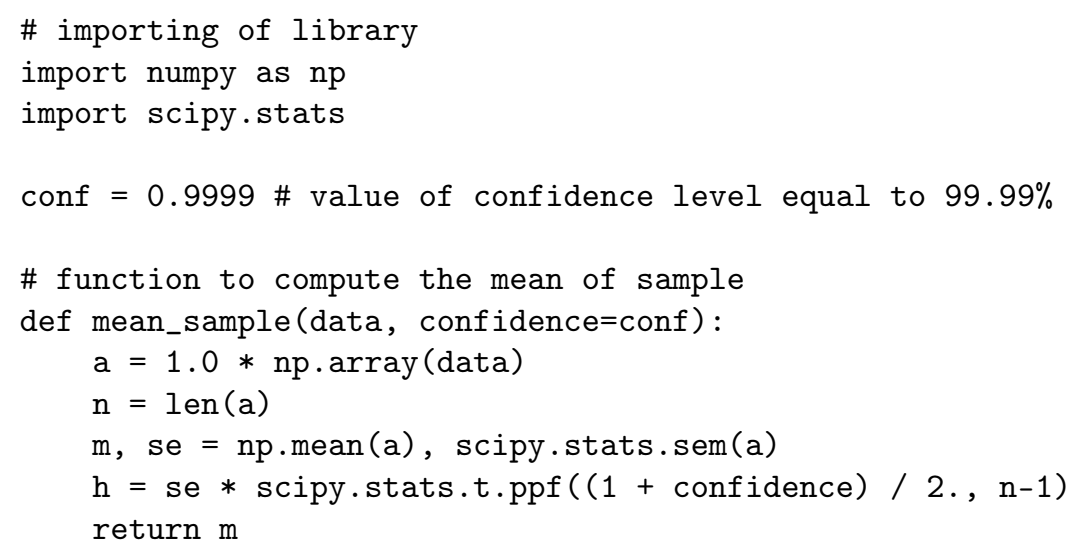




\section{REFERENCES}

Anjos, R.M.d. As rochas alcalinas da região de Jaguaquara-petrografia e litogeoquímica, Bloco Jequié-Bahia, Brasil (Alkaline rocks of the Jaguaquara region - petrography and lithogeochemistry, Bloco Jequié - Bahia, Brazil). Dissert. de Mestrado, Universidade Federal da Bahia, Salvador, 79 p, 2019.

Aragão, O.C. Imageamento tipo Sun Shading utilizando Derivadas Fracionárias de Dados Gravimétricos do Prospecto de Jaguaquara (Sun Shading imaging using fractional derivatives of gravimetric data from the Jaguaquara Prospect), 2014. Monografia (Bacharel em Geofísica), Universidade Federal da Bahia, Salvador, 70 p.

Barbosa, J.; Cruz, S.; Souza, J.d. Terrenos metamórficos do embasamento (The metamorphic terrains at crustal basement). Geologia da Bahia: pesquisa e atualização, CBPM 2012, 1, 101-201.

Blakely, R.J. Potential theory in gravity and magnetic applications; Cambridge University Press, 1996.

CBPM. Prospecto Jaguaquara (Jaguaquara Prospect), $11 p, 2014$.

Downey, A.B. Think stats; “ O’Reilly Media, Inc.", 128 p, 2011; p. 128.

Essa, K.S.; Munschy, M. Introductory Chapter: Mineral Exploration from the Point of View of Geophysicists. In Minerals; IntechOpen, 2019; pp. 4-12.

Freire, S.L.M. Aplicações do Método de Decomposição em Valores Singulares no Processamento de Dados Sísmicos (Application of the SVD method in seismic data processing). Tese de doutorado, Universidade Federal da Bahia, Salvador, 182 p, 1986.

Kamm, J.; Lundin, I.A.; Bastani, M.; Sadeghi, M.; Pedersen, L.B. Joint inversion of gravity, magnetic, and petrophysical data-A case study from a gabbro intrusion in Boden, Sweden. Geophysics 2015, 80, B131B152.

Kennedy, J. Particle swarm optimization. Encyclopedia of Machine Learning 2010, pp. 760-766.

Lanczos, C. Linear differential operators; SIAM, 581 , 1996; p. 581.

Olivier, R.; Hanqiang, C. Nearest neighbor value interpolation. Int. J. Adv. Comput. Sci. App/ 2012, 3, 2530.

Ribeiro, J.F.S. Avaliação geofísica do Prospecto Jaguaquara (Physical evaluation of Jaguaquara Prospect), 2018. Monografia (Bacharel em Geofísica), Universidade Federal da Bahia, Salvador, 58 p.

Shaw, R.; Srivastava, S. Particle swarm optimization: A new tool to invert geophysical data. Geophysics 2007, 72, F75-F83.

Silva, E.F.A.; Moraes, A.M.V.; Garrido, I.A.A.; Matos, V.B.M.M. Prospecto Jaguaquara: características geológicas e perspectivas metalogenéticas preliminares (Jaguaquara Prospect: geological characteristics and preliminary metalogenetic perspec- tives), in: $47^{\circ}$ Congresso Brasileiro de Geologia, Bahia, Brazil. 2014.

Singh, A.; Biswas, A. Application of global particle swarm optimization for inversion of residual gravity anomalies over geological bodies with idealized geometries. Natural Resources Research 2016, 25, 297-314.

Souza, I.C. Análise comparativa de cinco métodos de continuação para baixo aplicados a dados aeromagnéticos do Prospecto Jaguaquara (Comparative analysis of five downward continuation methods applied to aeromagnetic data from the Jaguaquara Prospect). Master's thesis, Universidade Federal da Bahia, Salvador, 2015.

Srivastava, S.; Agarwal, B. Inversion of the amplitude of the two-dimensional analytic signal of the magnetic anomaly by the particle swarm optimization technique. Geophysical Journal International 2010, 182, 652-662.

Wilken, D.; Wölz, S.; Müller, C.; Rabbel, W. FINOSEIS: A new approach to offshore-building foundation soil analysis using high resolution reflection seismic and Scholte-wave dispersion analysis. Journal of Applied Geophysics 2009, 68, 117-123.

Yuan, S.; Wang, S.; Tian, N. Swarm intelligence optimization and its application in geophysical data inversion. Applied Geophysics 2009, 6, 166-174.

E.M.S.A.: methodology (lead), inverse modelling, data analysis (lead), validation (lead), writing (lead). E.E.S.S.: methodology (supporting), data analysis (supporting), validation (supporting), writing (supporting).

Received on October 19,2020/ Accepted em February 5, 2021.

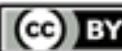

-Creative Commons attribution-type BY 